\title{
Powder and Solution for Beehive Dispersion Dosage Form
}

National Cancer Institute

\section{Source}

National Cancer Institute. Powder and Solution for Beehive Dispersion Dosage Form. NCI

Thesaurus. Code C149772.

Powder and solution intended for the preparation of a bee-hive dispersion by mixing the powder with the solution. The powder and the solution both contain active substance(s), or in some cases only the solution contains active substance(s). 